\title{
Analysis of Cadets Satisfaction to Medan Aviation Polytechnic Service Using Quality Function Deployment (QFD) Method
}

\author{
Liber Tommy Hutabarat \\ POLTEKBANG MEDAN \\ Medan, Indonesia \\ limasodara@gmail.com
}

\author{
Lisda Juliana Pangaribuan \\ AMIK MBP \\ Medan, Indonesia \\ lisdadavin@gmail.com
}

Submitted: Mar 26, 2020

Accepted: Apr 10, 2020

Published: Apr 10, 2020

\begin{abstract}
Education is an important factor in the development of science and the technology. Quality of service is an important element in the institution of education for the quality service of education that will produce high-quality graduates as well. The importance of service quality makes it a part of the Higher Education Quality Standards. Cadets Satisfaction to services is a benchmark to find out the quality of service at Medan Aviation Polytechnic. This research aims to determine the level of Cadets satisfaction to Medan Aviation Polytechnic service towards learning management standard services and standards for infrastructure facilities. The results of the study will be used as references in developing quality standards of Medan Aviation Polytechnic. The method used was Quality Function Deployment (QFD) method, with a total sample of 44 people. Analysis of the data is done with test validity, reliability, planning matrices and matrix House of Quality (HOQ). Analysis results shows the level of cadets satisfaction highest is the dimension Realibility to value the satisfaction of 4.01 followed by the dimensions of Assurance with the value of the satisfaction of 3.98, then the dimension Empaty to value the satisfaction of 3.97 and then at Responsivness dimension with satisfaction value 3.95 and the last is Tangibility dimension with satisfaction value 3.92 .
\end{abstract}

Keywords - QFD; Cadets Satisfaction; PlanningMatrix; HoQ Matrix

\section{INTRODUCTION}

Education world's is an important factor in the development of science, therefore technological progress must increasingly encourage educational institutions to provide good services for users of educational services in order to produce quality individuals. It is undeniable cadets satisfaction to education services should be kept. Therefore the level of quality of the education service system must always be improved.

Medan Aviation Polytechnic is the institution has the basic principle of meeting the demands and cadets needs because cadets needs can increase the productivity of education. Enhancement of Education productivity in Medan Aviation Polytechnic become main benchmarks for goals to be achieved, so analysis of Medan Aviation Polytechnic quality service satisfaction should be performed to obtain an understanding of cadets satisfaction to infrastructure and process learningservices. The way that can be taken is by trying to know and understand the expectations, perceptions of cadets and characteristics of educational services so that the priorities of the service can be known. National Higher Education Standards become a reference in preparation quality standards for the learning process and infrastructure. Assessment of satisfaction for service quality is very important to be carried out in the preparation of standards for the learning process and infrastructure in the Quality Assurance System. In addition, the implementation of the standard learning processes and infrastructures is important part of the instrument of accreditation of study 
programs and institutional accreditation. The results of the assessment of satisfaction for the standards of the learning process and infrastructure can also be input for institutions in order to improve and develop education.

Based on the Regulation of the Minister of Research, Technology, and Higher Education Republic Indonesia No. 44 of 2015 concerning National Standards of Higher Education, to get a goal of national education, efforts to improve the quality, amount, type, and specifications based on the use of facilities are in accordance with the characteristics of methods and forms of learning, must guarantee the implementation of the learning process and academic administrative services. Quality of service is a very important factor and has become an issue today. From this aspect it is known that the government plays an important role in encouraging national education through a variety of applicable rules and regulations.

Quality Function Deployment (QFD) or the distribution of quality functions is a tool used to support the implementation of TQM (Total Quality Management) and quality improvement programs to improve the performance of an educational institution that affects the improvement of consumer satisfaction or vice versa. This method is a method, a structured tool for assessing satisfaction so as to improve service quality is the Quality Function Deployment (QFD) method.

\section{Literature ReVIEW}

In research conducted by Kusumawardhani said that to improve service in institutional workshops is expected to be able to develop workshop services by paying attention to customer satisfaction (cadets) then services also need to be improved by improving and improving the quality of human resources such as training to support the ability of workshop assistants to handle problems in PUM workshops, however this research is limited to Workshop services so that input cannot be made to improve the quality standards of institutions. (Kusumawardhani \& Shafiq, 2018).

According to Claudia, the proposed improvements can be given to increase customer satisfaction including checking the availability of goods in goods on a scheduled basis ( 5 hours) from the opening hours of the store, then the company's strategy in selecting suppliers who become suppliers for its outlets must be more complete and quality, scheduling checking of suggestion boxes or customer service. But the results of this study cannot be applied to other agencies because the data processed is only based on 1 type of respondent, namely consumers who have shopped at the SUPER INDO Tembalang hypermarket (Claudia Gita \& Susanti, 2017).
In a study conducted by Andre Audi Havid et al. (2016) stated the service attribute "completeness of facilities and infrastructure in information media (internet)" shows the broadest tolerance zone and the attribute "comfortable seating conditions" is the narrowest tolerance zone. The QFD results show that the priority of the technical response given is providing employee performance training. (Andre A et al., 2016)

Elements academic services include elements of academic staff such as lecturers, elements of academic support staff are laboratory staff and academic administrative staff. Of course, in addition to human resources, the availability of other resources that support academic activities in the form of facilities and infrastructure will largely determine the quality of academic services provided by Suhendar \& Suroto (2014).

Service quality is a measure of how well the level of service provided is able to match customer expectations. Service quality is determined by the company's ability to meet the needs and desires of customers in accordance with customer expectations. (Tjiptono, 2012)

Various studies have been conducted on several types of services, and managed to identify five dimensions of characteristics used by customers in evaluating service quality. The five dimensions of service quality characteristics are Tangibles, Reliability, Responsiveness, Assurance and Empaty (Yamit, 2013)

Higher Education Standards used is standard on Minister of Research, Technology and Higher Education Regulation Republik Indonesia No. 44 of 2015 about Standar Nasional Pendidikan Tinggi (Republik Indonesia., 2015) and Amendment Minister of Research, Technology and Higher Education Republic Indonesia No. 50 of 2018. (Republik Indonesia, 2018)

According to Meriastuti (Ginting \& Halim, 2012) Quality Function Deployment (QFD) is a way to improve the quality of goods or services by understanding the needs of consumers and then linking with technical provisions to produce goods or services produced. QFD is a practice for designing a process in response to customer needs. QFD allows organizations to prioritize customer needs, find innovative responses to those needs, and improve processes to achieve maximum effectiveness (Tutuhatunewa, 2010).

The House of Quality (HOQ) matrix is tools for QFD representation (Azizah N. I. et al., 2018). HOQ use matrix to connect Voice of Customer and 
technical response. (Sutawijaya \& Pista, 2018) This matrix consists of two main parts namely the horizontal and vertical parts. The Horizintal section of this matrix contains information relating to consumers and this is called the customer table. The vertical part of the matrix contains technical information in response to consumer input, and is called a technical table. Customer information about consumers to provide information in the formation of the QFD method, while information techniques are respondents needed from consumers who are useful for distributors.

The process in QFD is carried out by compiling one or more matrices called The House of Quality. This matrix explains what the customer's needs and expectations are and how to fulfill them. The matrix called House of Quality in general can be seen in Figure 1.

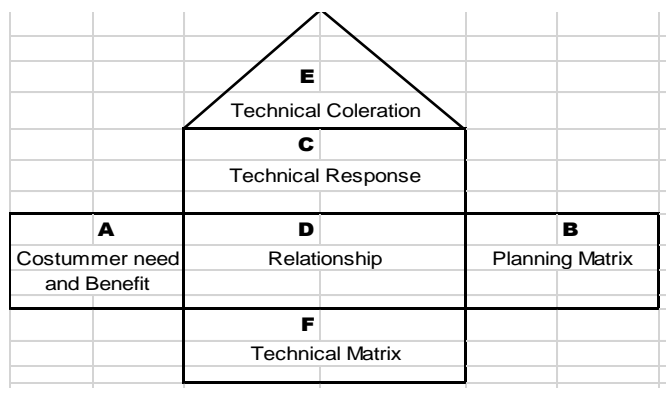

Figure 1. The House of Quality

(Source: Cohen, 2007)

Population is a generalization area consisting of objects and subjects that have certain qualities and characteristics determined by researchers to be studied and then drawn conclusions (Rusiadi et al., 2014).

Champion (1981) says that most statistical tests always include sample size recommendations. In other words, existing statistical tests will be very effective if applied to samples from 30 to 60. Even if the sample is above 500 , it is not recommended to apply a statistical test. (Basic Statistics for Social Research, Second Edition)

According to Gay and Diehl (1992), for descriptive research, the sample is $10 \%$ of the population, correlational research, at least 30 population elements, causal comparative research, 30 elements per group, and for experimental research 15 elements per group. (Hasim \& Yusuf, 2010)

Validity test is used to measure the validity or validity of a questionnaire, (Sugiono, 2010). Test the validity of this research using Microsoft Excel. Significance test is done by comparing the value of $r$ arithmetic with rtable for degree of freedom.

$$
\begin{aligned}
& \text { df }=\mathrm{n}-2 \\
& \text { Validity test } \\
& \text { ProbabIlistik= TINV }(\alpha ; \mathrm{df}) \\
& \text { Rtable }=\frac{\text { Probabilistik }}{\sqrt{d f}+\text { Probabilistik }^{2}}
\end{aligned}
$$

The reliability test is used to measure the consistency of respondents in answering the research questionnaire. The questionnaire is said to be reliable if the respondent's answer to the question is consistent or stable over time. The reliability test is used to determine the consistency of the measuring instrument, whether the measuring device used is reliable and remains consistent if the measurement is repeated. Reliability can be determined by using the following formula:

$$
\text { Reabilitas = k / (k-1)* }(1-\Sigma \sigma \mathrm{i} 2 / \sigma \mathrm{t} 2
$$

The instrument reliability of this study was calculated by the Alpha Cronbach formula with the minimum requirement to be considered reliable is> 0.7. (Sugiono, 2010).

In the planning matrix calculations performed are: a. Measurement scale $=$ total score of the assessment of cadets' perceptions with a Likert scale which is modified as follows : (Abdulrahman F \& Handayani, 2017)

1 = not very good / very unsatisfactory / never / incomplete / not important

$2=$ not good / low / rare / less complete / less important

3 = sufficient / sometimes / sufficiently complete / important enough

$4=\operatorname{good} /$ high $/$ frequent $/$ complete $/$ important

5 = very good / very high / always / very complete / very important

b. Level of importance $=$ Scoring score that most often appears

c. The level of satisfaction of cadets was made to determine the needs of cadets. Formula for calculate Voice of Cadets $=$ Total score atribut $/$ total sample.

Formula for calculating cadets satisfaction $=$ Total score attribute / number of samples.

d. Determination of Goal $=$ Target Score desired

e. Improvement ratios are made to determine the magnitude of changes made by management. Repair ratio formula $=$ Goal $/$ Taruna satisfaction level.

f. Selling Point with conditions

If the satisfaction level is $>3$, the selling point is 1.5 If the satisfaction level is $2-3$, the selling point is 1.2 If the satisfaction level is $0-2$, selling point is 1 (5) g. RowWeight is useful to find out the amount of improvement needs of cadets. Can be calculated by the formula: Row Weight = Importance * Repair Ratio * Point of Sale 
h. Normalized Weight can be calculated by the formula: Normalized Weight $=$ Row Weight for each attribute: Total Row Weight

Technical Matrix is conducted to determine the strength of the relationship between technical responses and cadets needs. The correlation value can be seen from the amount of Contribution Contribution $=($ Numerical Value $*$ Numerical Raw Weight)

Each relationship has its own weight value, if the relationship is very strong then the weight value is 9 , if the relationship is strong the weight value is 3 , if the relationship is weak the weight value is 1 , and if there is no relationship between the two, then the weight value is 0. (Kusumawardhani \& Shafiq, 2018)

\section{Proposed Method}

This is a descriptive study using survey methods to describe the gap between the expected services with services that have been perceived and Quality Function Deployment method to describe the development of services that will be recommended according to the needs of cadets. In this study, data collection was obtained by searching literature, field research in the form of interviews, questionnaires or direct observation of the actual situation. The variables observed in this study are the quality of service implemented by Medan AVIATION POLYTECHNIC to meet the National Standards of Higher Education, especially in the National Education Standards. The stages can be seen in Figure 2.

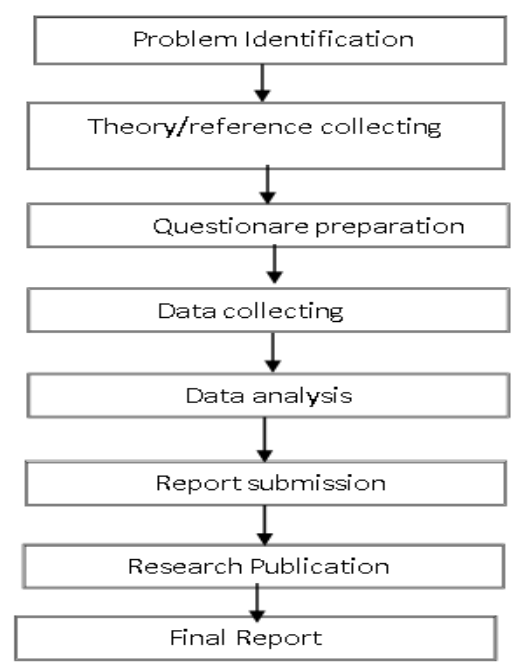

Figure 2. Research Method

Algorithm of Quality Function Deployment method (data analysis) :
A. The phase for collecting voice of customer

1. Knowing the attributes of the cadets desires

2. Knowing the perception of cadets

3. Conducting validity and reliability testing

4. Classifying attributes of cadets desires

B. Phase for compiling House of Quality Matrix

1. Make a Planning Matrix

2. Making Technical Responses as Characteristics of Medan AVIATION POLYTECHNIC Services.

3. Determine the relationship of technical parameters (how) and the desires of cadets (whats)

4. Calculate technical correlation (Technical matrix) and determine service priority

5. Making the House of Quality Matrix.

Algorithm QFD (Quality Function Deployment) in this study can be seen in Figure 3.

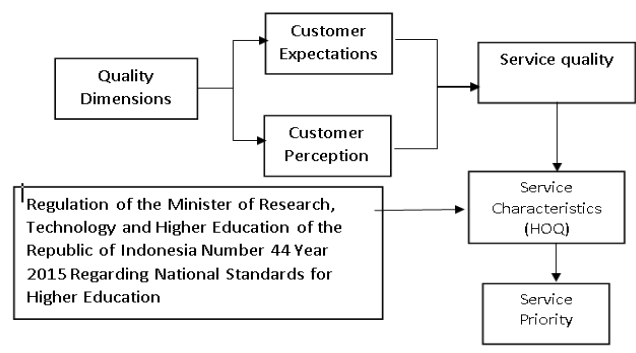

Figure 3. Algorithm QFD

This recearch uses 3 (three) independent variables, namely: Students Perception (X1), Student expectation (X2), Technical characteristics of service (X3) and 1 (one) dependent variable which is a form of educational service quality (Y). 3 independent variable in this reseach are student perception (X1), students perception as a customer is defined that the evaluation of the form of educational services received begins even before it interacts with the service provider itself ; Student expectation (X2), Student expectation as a customer is defined as a form of educational services expected by a cadets (customer) that he feels deserves to be received if he uses these educational services; Technical characteristics of services (X3), Technical characteristics are defined as technical services provided by management to cadets.

The variables used in the study are based on the Regulation Minister of Research, Technology and Higher Education Republic Indonesia No. 44 of 2015 concerning National Standards of Higher Education which specifically only addresses the National Standards of Education. National Education Standards will be grouped according to the five dimensions of service quality described by Zethaml, et al (2013) are: Tangible, Reliability, Responsiveness, Assurance, Empaty. 
Population in this recseach are all of cadets in Medan AVIATION POLYTECHNIC a number of 300 people. This research is a descriptive study, so the minimum number of samples is $10 \%$ of the population, so the number of samples used is 2 classes with a total of 44 people.

\section{RESULT AND DisCUSSION}

The first step in the research is to look for the attributes desired by cadets of Medan AVIATION POLYTECHNIC for the learning management services and the infrastructure provided. From the results of interviews and observations obtained several questions used as a questionnaire as an attribute of the Taruna desires. The items for the questionnaire:

Learning Management Standards, namely: 1. Submission of information on requirements and needs of cadets, 2. Administrative Services, 3. Provision of learning equipment, 4. Distribution of Schedules, 5. The lecturer gives time to explain the Module / Teaching material, 6. The suitability of PBM implementation.

Infrastructure Standards: 7. Information regarding student services, 8. Provision of students equipment, 9. Cleanliness of the study room, 10. Condition conditioning in the study room, 11. Condition of Chairs and Tables in the study room (furniture), 12. Learning Infrastructure Functions such as LCD / Projector, 13. Layout of Tables and Chairs and other equipment, 14. Lighting the study room, 15. Cleanliness in the Dormitory and the Dormitory environment, 16. Condition of Air Conditioning in the dormitory, 17. Completeness of cleaning tools, 18. Facilities functions (bathrooms, toilets etc.),19. Water Availability (Drinking water and water for other purposes), 20. Availability of electricity and other electricity-related facilities, 21. Availability of fast Internet access (WIFI) (IT and communication facilities), 22. Infrastructure conditions and arrangements (beds, chairs, cupboards, tables, etc.), 23. Lighting in the Dormitory, 24. Security in the Dormitory environment, 25. Cleanliness / Structure the sports room, 26. Cleanliness / Arrangement of art space, 27. Laboratory equipment supplies, 28. Art and sports extracurricular services, 29. Sports equipment, 30. Hospitality Service

30 questions are grouped into 4 sections, namely: PBM services; Classroom Conditions; Dorm Condition; Arts, sports and laboratories. Results of the questionnaire distributed to cadets (44 people) obtained the evaluation results of the cadets' perception of the management of learning and infrastructure: PBM services with an average value of 27.43 (Good/Satisfactory), Classroom Conditions with an average value of 32.36 (Good / Satisfactory), Boarding conditions with an average rating of 40.14 (Good /Satisfactory), Arts, Sports and Laboratories with an average rating of 22.46 (Good / Satisfactory).

After cadets perseption calculation process, then calculate sgnificant test. $\mathrm{df}=42$ and alpha $=0.05$ so rtable $=0.297315212$. And Reliability value $=0.960$. Reliability $>0.7$, so attribute is realiable

Based on the results of calculations, all the attributes stated are valid. and reliable so all attributes can be used as attributes of cadets expectation. From the calculation results the highest validity value is Lighting Room study $=0.862$ and the lowest validity value is lecturer gives time to explain the module / teaching material $=0.434$.

The next step is to group cadets expectations into five characteristic dimensions. Classification of attribute cadets expectations towards learning management services and facilities and infrastructure standards are:

1. Dimension Tangibility : Schedule Distribution (4), Study Room Cleanliness (9), Condition of Air Conditioning(AC) in Study Rooms (10), Condition of Chairs and Tables in the study room (11), Cleanliness in the Dormitory and the Dormitory environment (15), Condition of AC in dormitories (16), Completeness of Cleaning Equipment (17), Facilities Function (Bathroom, toilet) (18), Availability of Water (Drinking Water or water for other other purposes) (19), Availability of Electricity and Other Electrical Related Facilities (20), Infrastructure conditions and arrangements (beds, chairs, cupboards, tables, etc.) (22), Dormitory Lighting (23), Sports Room Cleaning / Arrangement (25), Art Space Cleaning / Arrangement (26), Laboratory equipment supplies (27), Sports equipment (29).

2. Dimension Realibity : Conformity of PBM implementation (6), Learning Infrastructure Functions such as LCD / Projector (12), Layout Tables and Chairs and other equipment (13).

3. Dimension Responsivnes : Submitting information on the requirements and cadets needs (1), Administrative Services (2), Information About Student Services (7), Arts and sports extracurricular services (28).

4. Dimension Assurance : Provision of learning equipment (3), Provision of student Equipment (8), Dormitory security (24), Internet Access (WIFI) Availability (21), Study Room Lighting (14). 
5. Dimension Empaty : Hospitality Service (30), Lecturer gives time to explain Module / Teaching material (5).

The importance level, the cadets satisfaction level and the improvement ratio are obtained from the calculation of Planning Matrix.

From the table it can be obtained that the highest average cadets satisfaction level lies in the dimensions of reliability with a satisfaction value of 4.01 followed by the Assurance dimension with a satisfaction value of 3.98 then on the empaty dimension with a satisfaction value of 3.97 then on the dimension of Responsivness with a satisfaction value of 3.95 and finally the Tangibility dimension with a satisfaction value of 3.92 .

While from the average repair ratio, the most need to be improved is the Tangibility dimension with the value of Improvement Ratio $=1.28$ followed by the dimension of Responsivness, the value of Improvement Ratio $=1.264$, then the dimensions of empaty, the value of Improvement Ratio $=1.261$, next is the dimension of Assurance, the value of Improvement Ratio $=1.259$ and the last dimension Realibility value Improvement Ratio = 1.248 .

The technical characteristics of service (X3) or the technical response for voice of customer of Medan AVIATION POLYTECHNIC, in this case the Quality Assurance Unit for are : Schedule distribution base on level and class, Sosializing hygiene culture, Scheduling maintenance of study room, Facilities suply comsumables, Scheduling maintenance of boarding room, Facilities provision of campus fasility, Maintenance of laboratory fasilities, Facilities conduct PBM monev on a schedule, Training to administration staff, Provide information online, Give reward to cadets who win competition accorging to extracurricular, Increase CCTV in the dormitory enviroment, Increase bandwidth and computer in campus are, Give excellent service system training to administration staff, Make lecture contract exposure in the first week in RPS.

After knowing the technical characteristics of service, a technical correlation is conducted to determine the relationship between the needs of the cadets and management response. The relationship is classified into 3 namely: very strong, strong and weak. The results of the analysis show a very strong relationship is correlation between : Schedule Distribution and Schedule distribution base on level and class, Condition of AC in study rooms and Scheduling maintenance of study room, Condition of chairs and tables in the study room and Scheduling maintenance of study room, Condition of $\mathrm{AC}$ in dormitories and Scheduling maintenance of boarding room, Completeness of Cleaning Equipment and Facilities suply comsumables, Facilities Function (Bathroom, toilet and Scheduling maintenance of study room, Availability of Water and Facilities suply comsumables, Availability of Electricity; Other Electrical Related Facilities and Scheduling maintenance of study room; Scheduling maintenance of boarding room, Laboratory equipment supplies and Maintenance of laboratory fasilities, Conformity of PBM implementation and Facilities conduct PBM monev on a schedule, Learning infrastructure functions and Scheduling maintenance of boarding room, Submitting information on the requirements and cadets needs and Provide information online, Administrative Services and Training to administration staff, Information about student services and Provide information online, Arts and sports extracurricular services and Give reward to cadets who win competition accorging to extracurricular, Provision of learning equipment and Facilities suply comsumables, Internet Access (WIFI) Availability and Increase bandwidth and computer in campus area, Hospitality Service and Give excellent service system training to administration staff, Lecturer gives time to explain Teaching material and Make lecture contract exposure in the first week in RPS.

Strong relationship is correlation betweens: Study room cleanliness and Sosializing hygiene culture, Cleanliness in the Dormitory and the Dormitory environment and Sosializing hygiene culture, Condition of AC in dormitories and Facilities provision of campus fasility, Facilities function and Sosializing hygiene culture, Dormitory lighting and Scheduling maintenance of boarding room, Sports room and art space cleaning and Sosializing hygiene culture, Laboratory equipment supplies and Facilities provision of campus fasility, Conformity of PBM implementation and Schedule distribution base on level and class.

Weak relationships are correlation betweens : Sports equipment and Facilities provision of campus fasility.

The last step, quality of education services for learning management standards and infrastructure facilities can be seen in Figure 4.

From the calculation of the House of Quality Matrix (HOQ) can be obtained the relationship between the needs of cadets and technical descriptors according to the highest order are: Scheduling maintenance of study room facilities with a weight of 1.952; 
Procurement of consumables with a weight of 1.177 ; Scheduling of maintenance of dormitory facilities with a weight of 0.664 ; Providing information on online cadets services weighing 0.589 ; Procurement of campus facilities checklist with a weight of 0.408 ; The division of schedules by force and class with a weight of 0.394 ; To socialize clean culture with a weight of 0.332 ; Provide excellent service system training to administrative staff with a weight of 0.320 ; Adding lecture contract exposure in the first week of the RPS with a weight of 0.3 ; Give rewards to cadets who win the competition according to extracurriculars with a weight of 0.298 ; Provide training to administrative staff with a weight of 0.291 ; Conduct PBM monev on a scheduled basis with a weight of 0.288 ; Adding internet and computer bandwidth in the campus area with a weight of 0.286 ; Maintenance of laboratory facilities with a weight of 0.262 ; Adding CCTV in the dormitory environment with a weight of 0.123 . 


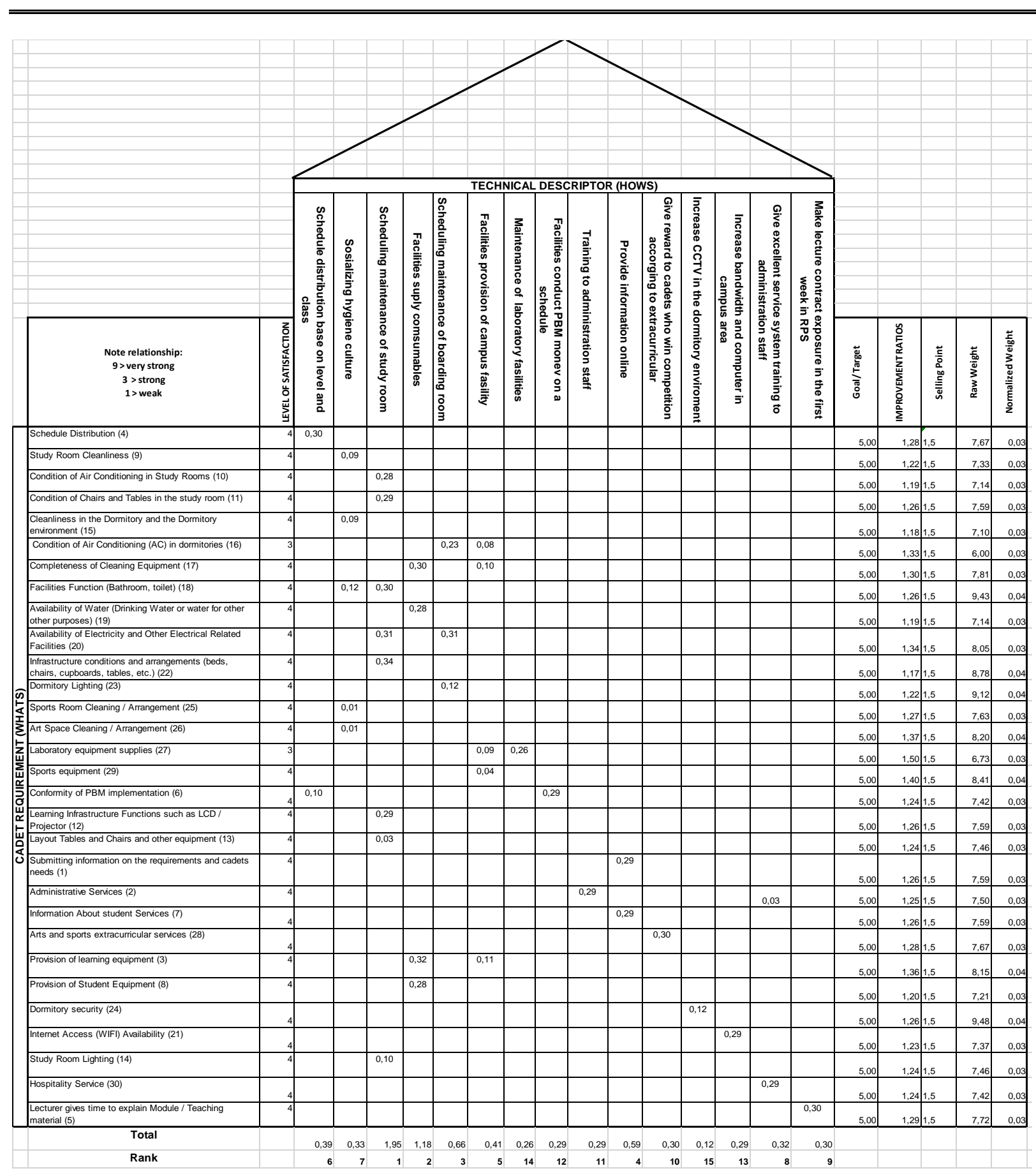

Figure4. Matrix House Of Quality (HOQ)

\section{Conclusion ANd Suggestion}

The results of the analysis and discussion, the following conclusions are obtained:

1. There is a significant difference between the hopes / desires of cadets and the cadets' perceptions of learning management services and the facilities of the Medan POLYTECHNIC AVIATION facility.

2. Based on the importance level of service attributes that are very important for the Medan AVIATION POLYTECHNIC cadets there are 4 namely: Level of importance of the Facility Function 
(Bathroom, toilet), Condition and infrastructure arrangements (beds, Chairs, Cabinets, tables etc.), Lighting in the Dormitory, Security boarding environment.

3. From the results of the analysis of satisfaction of cadets towards learning management services and facilities of Medan AVIATION POLYTECHNIC, the highest level of satisfaction of cadets is the dimension of reliability with a satisfaction value of 4.01 , followed by the Assurance dimension with a value of satisfaction 3.98 and then on the dimension of empaty with a value of satisfaction of 3.97 then on the Responsivness dimension with a satisfaction value of 3.95 and the last is the Tangibility dimension with a satisfaction value of 3.92.

4. From the analysis of the improvement ratio, the increase that must be done by Medan AVIATION POLYTECHNIC for the highest learning management and infrastructure is the Tangibility dimension with the value of Improvement Ratio = 1.28 followed by the dimension of Responsivity, the value of Improvement Ratio $=1,264$, then the empathy dimension, the value of Improvement Ratio $=1,261$ hereinafter is the Assurance dimension Improvement Ratio value $=1.259$ and the last dimension is the Reliability dimension Improvement Ratio value $=1.248$.

5. Based on the analysis using the QFD method, to meet the cadets needs, the priority of Medan AVIATION POLYTECHNIC service that can be used as a Quality Standards of learning management and facilities is the Scheduling of maintenance of study room facilities with a weight of 1.952 followed by the procurement of consumables with a weight of 1.177 then scheduling maintenance of dormitory facilities with a weight of 0.664 , providing online cadets service information with a weight of 0.589 then procuring a campus facility checklist with a weight of 0.408 followed by schedule distribution by force and class with a weight of 0.394 , socializing a clean culture with a weight of 0.332 , providing excellent service system training to staff administration with a weight of 0.320 , adding exposure to the college contract in the first week of the RPS with a weight of 0.3 , giving rewards to cadets who win the competition according to extracurriculars with a weight of 0.298 , providing training to administrative staff with with a weight of 0.291 , scheduled PBM monitoring and evaluation with a weight of 0.288 , increasing internet and computer bandwidth in the campus area with a weight of 0.286 , maintenance of laboratory facilities with a weight of 0.262 and the last addition of CCTV in the dormitory environment with a weight of 0.123

Suggestions for further research

1. To obtain a quality standard quality of learning management infrastructures and facilities in Medan AVIATION POLYTECHNIC advisable to do a questionnaire and analysis for lecture and staff as internal custumer.

2. To obtain quality standards beyond the SNDIKTI Quality Standards it is recommended to use the QFD method in setting standards for all quality assurance pen standards with subjects that suit your needs.

\section{REFERENCES}

Abdulrahman F, I., \& Handayani, A. (2017). House Of Quality Sebagai Pengendalian Kualitas Layanan di Lembaga Pendidikan Muhammadiyah. Prosiding Seminar Nasional AIMI (pp. 12-25). Jambi: AIMI.

Alibeigi, M. (2015). A Robust Statistical Color Edge Detection for Noisy Images. SemanticScholar.

Andre A et al. (2016). Analisis Kepuasan Mahasiswa Terhadap Fasilitas Dan Layanan Karyawan Di Teknik Industri Universitas Diponegoro Dengan Zone Of Tolerance Dan Quality Function Deployment. Industrial Engineering Online Journal, V(1).

Azizah N. I. et al., R. L. (2018, Agustus 2). Penerapan Metode Dan Quality Function Deployment (QFD) Dalam Memenuhi kepuasan Konsumen Pada Industri Komponen Otomotif. Jurnal Teknik Industri, XIX(2), 127-136. doi:10.22219

Claudia Gita, P., \& Susanti, A. (2017). Analisis Kepuasan Pelanggan Menggunakan Metode Importance Performance Analysis Dan Quality Function Deployment Di Hypermarket Super Indo Tembalang . Industrial Engineering Online Journal., VI(4).

Cohen, L. (2007). Quality Function Deployment: How to Make QFD Work For You. Virginia: R.R Donnelly Horrisonburg.

Ginting, M., \& Halim, D. I. (2012, April ). Usaha Peningkatan Kualitas Pelayanan Perpustakaan Ukrida Dengan Metode Serqual Dan Quality Function Deployment (QFD). Jurnal Teknik dan Informatika Komputer., I(2), 182-195. 
Hashem, H. F. (2009). Adaptive technique for human face detection using HSV color space and neural networks. National Radio Science Conference. IEEE.

Hasim, \& Yusuf, A. (2010). Determining Suffiency Of Sample Size In Management urvey Research Activities. International Journal of Organisasional Manajemen \& Entepreneurship Development, 6(1), 119. 130.

Kusumawardhani, A., \& Shafiq, N. (2018, Desember 28). Teknika : Engineering and Sains Journal . Implementasi Metode Quality Function Deployment (QFD) Dalam Menganalisis Kualitas Pelayanan Pada Bengkel Politeknik, II(2), 95-102.

Pittsburgh, U. o. (2019, February 18). University of Library System. Retrieved from Citation Styles: APA, MLA, Chicago, Turabian, IEEE: APA 6th Edition: https://pitt.libguides.com/c.php?g=12108\& $\mathrm{p}=64730$

Republik Indonesia. (2018). Amandement Menteri Riset, Teknologi, Dan Pendidikan Tinggi . Tentang Standar Nasional Pendidikan Tinggi, Jakarta.

Republik Indonesia. (2015). Peraturan Menteri Riset, Teknologi, Dan Pendidikan Tinggi. Tentang Standart Pendidikan Tinggi Nasional, Jakarta.

Rusiadi et al., S. N. (2014). Metode Penelitian Manajemen, Akuntansi dan Ekonomi Pembangunan. Medan: USU Press.

Sugiono, D. (2010). Statistika Untuk Penelitian. Bandun: Alfabeta.

Sutawijaya, A. H., \& Pista, S. (2018, September 2). Evaluasi Pelayanan Publik Produk Hukumonline.com Untuk Mengetahuio Kebutuhan Pelanggan Kasus PT. Justika Publika. JDM, I(2), 32-45.

Tjiptono, F. ( 2012). Service Management Mewujudkan Layanan Prima. Yogyakarta: Penerbit Andi.

Tutuhatunewa, A. (2010). Aplikasi Metode Quality Function Deployment Dalam Pengembangan Produk Air Minum Kemasan. ARIKA, 11-19.

Yamit, Z. (2013). Manajemen Kualitas Produk \& Jasa. (Vol. VI). Yogyakarta, D.I.,Yogyakarta, Indonesia: Penerbit EKONISIA. 